部位は右上肺野で 220 件，最も多い所見は円形陰影で 151 件であった。性・年齢と有所見率の関係は男子 $16 \%$, 女子は $10 \%$ で，両性とも高齢群ほど高率であった。肺 門腫脹は 20 墄代男子で多く $1.2 \%$ に, 囊胞状陰影（ブラ） は男性に多く 50 歳以上で $3.4 \%$, 脊柱側彎は女性に多く, 20 歳代で $1.3 \%$ にみられた，有所見例に対する処置は， 浸潤影で $45.5 \%$, 腫瘤影で $40 \%$ と高率に要観察となった。 繊維化は医師により斑状影などと表現される場合があ り，所見の記載法には検討すべき点がある。

\section{0. 振動障害患者の温冷覚閾值測定}

榊原久孝 (名大・医・保健) 樋端規邦（徳島健生病院）

平田 衛 (大阪公衛研)

細い未梢神経線維の障害を評価する目的で, 振動障害 での温冷覚閾值測定の有効性について検討した。振動障 害患者 50 名と健常対照者 29 名の左右第 3 指で, 温冷覚 閾值, 振動覚閾值 $(125 \mathrm{~Hz})$, 痛覚閾值（注射針方式） を测定した。温冷覚閾值のいずれの指標でも，振動障害 患者は健常対照者よりも有意な鈍磨を示した。また，振 動障害の末梢神経障害ストックホルム・ワークショップ 症度分類の症度上昇にしたがって, 温冷覚閾值も悪化す る傾问が認められた，各測定值間の相関をみると，温冷 覚閾值は，振動覚閾僆よりも痛覚閾值との相関が強い傾 向がみられ，それも温覚でより強い傾向がみられた。今 回の测定值で特異度が $90 \%$ 前後になる值を基準にする と, 痛覚閾值では敏感度が $85 \%$ 前後なのに対し，温冷 覚閾值の各指慗は $90 \%$ ～95\% 前後の值を示した。今回 の結果は, 振動障害患者の末梢神経障害の評価において, 温冷覚閾值測定の有用性を強く示唆するものであった。

\section{1. 中高年労働者における泌尿器科的自覚症状}

○斉藤政彦，榊原一惠（大同特殊鋼 星崎診療所） 池山真治，浜松昭雄，小森義隆（大同病院）

伊藤宜則 (藤田保健衛生大学 衛生学部 公衆衛生)

ある事業場の 50 藏から 60 歳までの男性 447 人を対象 に泌尿器科的自覚症状のアンケート調査を行った。その 結果 $51.2 \%$ の人が夜間に時々あるいは每日排尿に起きる と答えた。一部の人は既に前立腺肥大症に罹患している 可能性が示唆された。また技術系（高卒現場従事者）は 主事技師系 (大卒事務職者) に比較して一日の排尿回数 を多いと自覚する人が有意に多かった。これは作業現場 でラインに乗って働いている従業員はトイレにいく時間 が制限されるので，排尿回数を多いと自覚するためでは ないかと推測された。一方性欲に関する質問では主事技 師系は技術系に比較して昔から淡白な人が多く，以前は 強かった，あるいは現在も強い方だと答えた人の割合が 有意に低かった。一般的に性欲はストレスに対して鋭钽 に反応して低下する，ストレスにさらされやすい中高年
管理職（主事技師系）に性欲の低い人が多いのは，ス卜 レスの強さを反映したためと考えられた。

\section{2. 定期健康診断での体脂肪率測定}

$\bigcirc$ 福井 明, 杉本日出子（豊田工機株式会社：診療所） 成人病の重要な要因である肥満の判定は簡単ではなか ったが生体インピーダンス方式の体脂肪計の開発により 体脂肪の測定が簡単になった。そこで，定期健康診断時 に体脂肪測定（オムロン HBF-300）を実施し，Body Mass Index（以下 BMI）や血中総コレステロール值と 対比検討した.

正常群（BMI 24 未満かつ体脂肪率 $20 \%$ 未満）では総 コレステロール高值の者は 1372 人中 187 人 (13.6\%), 見かけ肥満群 (BMI 24 以上かつ体脂肪率 $20 \%$ 未㢼) 135 人中 30 人 $(22.1 \%)$, かくれ肥満群 (BMI 24 未満か つ体脂脏率 $20 \%$ 以上） 430 人中 150 人 (34.9\%) 肥満群 (BMI 24 以上かつ体脂肪率 $20 \%$ 以上) 523 人中 195 人 $(37.3 \%)$. かくれ肥満群と肥満群の間のみ有意差がなく, それ以外はすべて有意差があった。

体脂肪率測定により BMIのみで判定していては見落 としてしまう成人病危険群（かくれ肥満群）を拾い上げ ることができた。

\section{3. アジア系留学生の血清脂質に関する研究}

○出龍郎 (愛知学院大・保健センター) 山田玩之（愛知医科大・産業保健科学: ンタ一） 近年，食習慣の欧米化により肥満や高脂血症が堌加し つつあり, 冠動脈疾患や脳血管障害の原因となってきて いる，当大学における外国人留学生約 300 名中，アジア 系留学生 100 名を対象に，食生活を中心としたライフス 夕イル調査を，また脂質代謝を中心とした血液生化学的 検査を実施した。この結果から血清脂質の異常所見と食 生活の関係を検討し, 対照の日本人学生 30 名と比較し た.さらにリポ蛋白分画を測定し midband (IDL) 出現 例と smallLDLを測定して脂質代謝全体の把握を行い, 高脂血症の型判定を行った。男女別ではBMI， T-G， HDLでそれぞれ有意差を認めた。リポ蛋白分画では， midband と smallLDL 雨者あるいはどちらかが認められ る者が $12 \%$ にみられた。特に， smallLDLを有するもの は, 高 $\mathrm{T}-\mathrm{G}$ と低 HDL を呈し, 今後冠動脈疾患や隠血管 障害の発症率が高いと思われる，以上より，脂質代謝異 常が認められる留学生においては，早急に栄養指導を含 めた生活習慣の改善が必要と考えられた。

\section{4. 職場の健康管理に対する東洋医学の導入}

丹村敏則 (NTT 東海健康管理センター)

【緒言】職場の健康管理に東洋医学的アプローチの導入 を行った。【方法】今回は健康管理の中でも, ストレス, VDT 障害, 疲労, 生活習慣病などの健康指導に重点を 